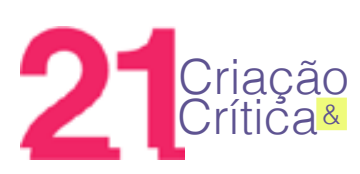

\title{
A trajetória de Leo Sammer em 2666, de ROBERTO Bolaño
}

\author{
Notas sobre ética, autonomia e responsabilidade
}

\begin{abstract}
Antonio Barros de Brito Junior ${ }^{1}$
Resumo: Em seu romance 2666, Roberto Bolaño apresenta-nos a personagem de Leo Sammer, funcionário nazista encarregado do transporte de trabalhadores e mantimentos para o Reich. Um dia, Sammer recebe por engano quinhentos judeus oriundos da Grécia e destinados aos campos de extermínio. Sem poder devolver os judeus para seu lugar de origem, Sammer recebe a ordem de exterminá-los. A partir deste fato, desdobra-se toda uma dimensão ética da personagem, que será o tema deste artigo. Primeiramente, Sammer é comparado à figura histórica de Adolf Eichmann, um proeminente nazista, a fim de avaliar a sua responsabilidade e a sua culpa no contexto do regime totalitário. Depois, a orientação ética de Sammer é analisada com base nas ideias de Ricoeur, Badiou e Lévinas, considerando questões como o Mesmo, o Outro e a autonomia do sujeito diante do Mal. Por fim, o artigo conclui que o discurso ambivalente da defesa de Sammer, na verdade, é a mera repetição do padrão totalitário do qual ele insistentemente tenta se descolar.
\end{abstract}

Palavras-Chave: Ética; Autonomia; Totalitarismo; Roberto Bolaño.

\section{The tRajectory of Leo Sammer in ROBerto bolaño’s 2666: NOtes on ethics, AUtONOMy AND RESPONSABILITY}

AbStRACT: Roberto Bolaño's novel 2666 introduces to the reader Leo Sammer, a Nazi official who was in charge of the transportation of workers and supplies for the Reich. All of a sudden, Sammer receives by mistake a shipment of five hundred jews coming from Greece and a few days later the order to exterminate them. This episode and its ethical consequences yield the present article. First of all, Sammer is compared to Adolf Eichmann, a prominent member of the Nazi Party, in order to evaluate Sammer's responsibility and guilty in the context of the totalitarian regime. Secondly, the ethical orientation of Sammer is seen from the perspective of Ricoeur's, Badiou's and Lévinas' respective ideas concerning the Self, the Other and the autonomy of the individual facing the Evil. Finally, the article affirms that the ambivalent discourse of Sammer is, in fact, the repetition of the totalitarian pattern from which he persistently tries to detach himself.

KEYwORDS: Ethics; Autonomy; Totalitarianism; Roberto Bolaño.

2666 é um dos romances mais devastadores do século XXI. Não apenas pela complexidade e riqueza dos temas, que impressionam o leitor a cada novo episódio, conforme vai se desenrolando o novelo narrativo ao longo dos cinco livros - independentes, mas interconectados -, que compõem a obra-prima de Roberto Bolaño. Isso se deve também ao profundo sentimento de angústia, pavor e pesar que as histórias de violência, de abandono, de devastação e, sobretudo, de feminicídio nos causam. De algum modo, o mosaico tenebroso do romance ("um oásis de horror em meio a um deserto de tédio", de acordo com a epígrafe emprestada de Baudelaire) desvela, em maior ou menor grau, e com mais ou menos acuidade, as diferentes manifestações do Mal e da decadência moral de uma sociedade que já não pode mais se pautar por nenhum tipo de utopia.

Derrotadas as ideologias de esquerda de uma geração que, segundo o próprio Bolaño, dedicou sua vida e seus melhores esforços (entre eles seus poemas e seu talento literário) a uma causa que se mostrou perdida tão logo os seus partidários alcançaram o poder (BOLAÑO, 2004); desfeitos os sonhos de uma geração que acreditou na revolução dos costumes por força do envolvimento na cultura e na política; enfim, enterradas as esperanças de transformação da sociedade pela via política e cultural, restou à literatura, a julgar pelas obras de Bolaño, a missão (não exatamente civilizatória!) de mergulhar no caos e na devastação do mundo do pós-Guerra e das utopias falidas para acusar a própria civilização pelas mazelas da vida cotidiana, erigindo um antimonumento contra a barbárie. 


\section{1 chicaso}

Nesse sentido, a história do Ocidente no século XX - especialmente a da América Latina, epitomizada no México assolado pelo narcotráfico e pela promiscuidade e ineficiência do poder público - é arrastada para o livro de Bolaño através de um emaranhado de episódios que, se por um lado não pretende desenvolver uma necessária relação de causalidade entre, por exemplo, a violência da Segunda Guerra, o linchamento de um taxista paquistanês e os feminicídios na cidade fictícia de Santa Tereza; por outro, certamente manifesta a típica sensibilidade apocalíptica fin de siècle, que escancara a falência da dimensão ética em escala global. ${ }^{2}$

Porém, nos episódios que compõem 2666, há um que se destaca justamente pelo fato de apresentar uma narrativa pessoal muito contundente em um contexto particularmente sensível na história do século XX. Trata-se da história de Leo Sammer, funcionário do escalão intermediário no Partido Nazista, encarregado de fornecer trabalhadores e mantimentos para o Reich a partir de um escritório instalado no interior da Polônia, e que um dia recebe por engano um comboio de quinhentos judeus, homens, mulheres e crianças, provenientes da Grécia e extraviados no caminho para o campo de extermínio de Auschwitz.

A história de Sammer é contada em um momento singular: Hans Reiter (vulgo Benno von Archimboldi, o protagonista da quinta e última parte do livro, "A Parte de Archimboldi") e Sammer estão detidos em um campo de prisioneiros montado por soldados norte-americanos nos arredores de Ansbach, na Baviera. Primeiramente, Reiter o conhece pelo nome de Zeller, mas tão logo eles travam conhecimento, Sammer revela seu verdadeiro nome. Ali, eles e outros prisioneiros alemães são interrogados a fim de se detectar colaboradores do regime nazista e criminosos de guerra. Diferentemente de Reiter, que não havia matado ninguém na Guerra, mesmo tendo se envolvido em missões principalmente na Rússia e na Romênia, Sammer demonstra um grande medo de ser interrogado. Após travar uma boa relação com Reiter, Sammer lhe confessa as razões de seu desconforto, já visível aos olhos do companheiro de prisão: como funcionário da administração ligado ao Partido Nazista, Sammer é um alvo dos aliados, que provavelmente querem enviá-lo a um tribunal pelos crimes de guerra. Porém, acima disso, está a verdadeira razão pela qual o oficial nazista tem medo: Sammer mandou assassinar a quase totalidade dos quinhentos judeus gregos que recebera por engano. Essa confissão, no entanto, está permeada de nuances que escancaram a crise ética de uma sociedade totalitária inteiramente dedicada à administração da morte pelas vias burocráticas. Entre a chegada por engano dos judeus e o seu extermínio, há toda uma escalada do Mal e do absurdo da violência sem rosto e sem compaixão, que faz com que esse episódio de 2666 seja tão impactante quanto os feminicídios da quarta parte do livro.

2 Apenas a título de esclarecimento, há aqui algumas informações que podem ajudar o leitor ou a leitora deste artigo a atravessar este parágrafo. O romance 2666 foi publicado postumamente, apesar de Bolaño ter quase concluído a revisão integral do material. Pelo que nos consta (ver MARISTAIN, 2014), apenas "A Parte dos Crimes", a maior entre as cinco que compõem o romance, não foi finalizada antes da morte do autor, que se dedicou ao livro durante os anos finais do século XX até a sua morte em julho de 2003 (o romance saiu um ano mais tarde). Em princípio, Bolaño premeditou publicar as cinco partes separadamente, tendo em vista a manutenção dos filhos após sua morte por deficiência hepática. Contudo, a ex-esposa de Bolaño, Carolina López, por sugestão de Ignacio Etchevarría, crítico literário amigo de Bolaño e uma espécie de "avalista literário" do espólio do escritor, decidiu por bem publicar o livro em um único volume, com mais de mil páginas. Cada uma das partes é bastante autônoma em relação às outras; contudo, um fio comum as une, de modo mais ou menos explícito e intenso: os assassinatos de mulheres na cidade fictícia de Santa Tereza, na fronteira do México com os EUA. Com isso, o trânsito das diferentes personagens principais, que têm sempre um elo em comum, por diferentes cidades, é marcado pelas vivências de cada uma em particular, expondo não só os dramas pessoais, triângulos amorosos etc., mas também a fragmentação temática que remete aos mais variados contextos históricos, e que tangencia (ou às vezes mergulha de cabeça) na violência frenética e no Mal absoluto, através de uma conexão mundial inusitada. Em relação aos episódios mencionados - a Segunda Guerra, o linchamento do taxista paquistanês e os feminicídios - eles se encontram, respectivamente, em "A parte de Archimboldi", "A parte dos críticos" e "A parte dos crimes" (embora, no caso destes últimos, há referência explícitas nas outras quatro partes do livro). 


\section{1}

É impossível, aliás, não traçar um paralelo entre Sammer e determinados funcionários reais do regime nazista, cujas atrocidades vieram à luz quando dos julgamentos dos crimes em tribunais como o de Jerusalém. Suspeito, inclusive, que Bolaño - mestre em camuflar personalidades reais em personagens ficcionais e em dispor de muita erudição e de um amplo conhecimento acerca da literatura sobre guerra (ver MARISTAIN, 2014) - coloca por trás de Sammer a figura de Adolf Eichmann, membro do partido nazista encarregado da logística de transporte dos judeus para os campos de extermínio. Os crimes de Eichmann foram revelados à sociedade em virtude da cobertura jornalística do seu julgamento em 1961 - cobertura que teve, entre outras, a importante contribuição de Hannah Arendt, que não apenas acompanhou as sessões do julgamento, transcrevendo passagens e dando detalhes sobre a atmosfera geral daqueles dias, como também teceu teses imprescindíveis acerca daquilo que, na visão dela, se configurou como a "banalidade do mal", isto é, a sustentação da defesa de Eichmann de que ele fizera tudo o que fez apenas porque, se não o tivesse feito, outros o teriam, ou - o que é ainda mais escandaloso - justamente porque era Eichmann, com sua consciência moral, e não qualquer outro naquele posto que permitiu "atenuar" o evento que, do contrário, teria sido ainda mais catastrófico (ARENDT, 1999).

Sammer, nesse sentido, parece exibir os traços morais característicos de Eichmann: uma fala "doce e baixinha", uma consciência bastante aguda da sua responsabilidade para com o trabalho, uma imago de si que revela um (falso) zelo para com o próximo e uma história familiar perpassada por infortúnios (o que o faz supor, de modo relativamente paranoico, que é vítima do sofrimento tanto quanto qualquer outra alma na terra). Sammer não se enxerga como agente do Mal, mas sim como parte de um mecanismo, de uma estrutura mais ampla, que tem como valor o trabalho, a responsabilidade para com as hierarquias, e a dignidade pessoal e profissional que se granjeia quando o empregado faz, a despeito de sua própria convicção, aquilo que lhe pedem.

$\mathrm{Se}$, aos olhos do "inimigo" (neste caso, os soldados americanos que detêm o poder sobre a vida dos prisioneiros de guerra alemães), Sammer é um criminoso cruel e impiedoso, aos olhos do regime totalitário nazista, porém - e na visão do próprio Sammer -, ele tem o seu valor, na medida em que respeita as normas de conduta do Partido. Essa aparente ambiguidade de um sujeito consciencioso e autônomo, mas ao mesmo tempo maquinalmente subordinado à perversidade, é, contudo, desfeita, quando levamos em conta a trajetória de Sammer, à luz dos reais vilões nazistas. Quando the chega a informação do desembarque dos judeus, Sammer não titubeia e busca alternativas de se desfazer deles mediante telefonemas constantes para as autoridades do Estado. À primeira vista, seu desejo de se livrar dos judeus consiste em transportá-los para outro lugar - ou seja, fazer o que ele sabe melhor, usar o seu conhecimento não para mitigar o sofrimento evidente nas figuras emaciadas dos judeus, mas simplesmente para manter organizado o território que ele administra. Desfazer o engano e salvar-se enquanto funcionário exemplar é, nesse primeiro choque do encontro com a verdade do regime nazista (o transporte e o extermínio dos judeus, bem entendido), a única meta de Sammer. Fracassadas, no entanto, as suas tentativas de realocar os judeus, Sammer começa então a demonstrar por eles um zelo que, tanto para o leitor, quanto para os possíveis procuradores e juízes de sua narrativa (portanto, para Reiter e, consequentemente, para a posteridade), é não apenas insuficiente do ponto de vista humanitário, mas de certo modo só serve para aliviar-Ihe a consciência, fazendo-o colocar-se no lugar de um verdadeiro benfeitor. 


\section{1}

Na viagem morreram oito judeus. O oficial mandou formar os sobreviventes. Não tinham bom aspecto. Ordenei que os levassem para um curtume abandonado. Disse a um dos meus funcionários que fosse à padaria e comprasse todo o pão disponível para reparti-lo entre os judeus. Mande pôr na minha conta, disse, mas vá rápido. Depois fui para o escritório despachar outros assuntos urgentes. (BOLAÑO, 2010, p. 716) ${ }^{3}$

Oferecer pães aos judeus - gesto bastante cristão da parte de Sammer - é um paliativo que nem pode mascarar a vilania da solução final. É notável, nesse sentido, que o fato, que entra na conta das benfeitorias desse "réu virtual", só pode ter como efeito fazer-nos pensar e sentir que, o que podia ser feito, estava sendo feito. É quase um "apaziguamento preventivo" da revolta do leitor, que receberá em pouco tempo a notícia do aniquilamento dos judeus por responsabilidade de Sammer. Além disso, é uma tentativa de reconstruir o caráter sob o prisma da ética, desvinculando o Bem do Mal na vã tentativa de assumir a responsabilidade pelo Bem e isentar-se sobre o Mal. O pão, sabemos depois, não é suficiente para todos os judeus, assim como não é suficiente a acomodação no curtume e não são suficientes os cobertores fornecidos aos judeus para que se aqueçam do gélido inverno polonês - cobertores que, "se forem solidários, cada judeu dividirá [...] com o outro, senão problema deles, mais eu não posso fazer", segundo as palavras do próprio Sammer (BOLAÑO, 2010, p. 721). Tudo isso, por outro lado, "é suficiente", especificamente naquilo que toca à construção da autoimagem de Sammer, em prol da justificação da sua inocência.

Se Sammer tenta distinguir a sua responsabilidade pessoal da responsabilidade coletiva do Partido é porque, no senso comum (mas - ouso dizer - inclusive nos meios "ilustrados"), impera a concepção de que nos regimes totalitários a autonomia do sujeito quanto ao seu próprio percurso ético está completamente determinada de fora. Haveria uma verdadeira heteronomia moral: quem decide sobre o certo e o errado é supostamente o Grande Outro, alteridade sem rosto, constituída fora do tempo e do espaço presentes, abstrata em todos os sentidos, mas que se faz notar cotidianamente nas microfibras do aparato burocrático. Dentro dessa concepção, o certo e o errado, o Bem e o Mal, não são mais juízos pessoais, como não podem ser jamais as decisões, os pensamentos, os desejos. Tudo se dissolve na figura desse Grande Outro - que a genialidade literária de Orwell (2009) nos legou em chave distópica -, de modo que a violência totalitária infiltra-se por todos os poros da sociedade, desfazendo laços e recriando relações mediante um pensamento e uma ética unitários.

A produção do Um, por meio da determinação total da vida, suspenderia o horizonte absolutamente individual do sujeito iluminista, cooptaria seu corpo e sua libido a fim de melhor realizar o ideal de uma comunidade falsamente orgânica, que tentaria de algum modo refundar a suposta organicidade primordial da comunidade ariana (ou qualquer outra), expelindo à força qualquer alteridade, radical ou não, que se mostraria como um obstáculo para a comunidade - a alteridade política, a alteridade étnica etc. (Aliás, o totalitarismo é racista também porque projeta no passado a arché da raça, a origem sem mistura da comunidade integral, da comunidade indiferenciada, da unidade total dos seus membros, forçando a concretização sobre o plano social daquilo que supostamente era espontâneo antes da degeneração e da heterogenia.)

3 Cotejei a tradução de Eduardo Brandão com o original e não detectei, nessa e em outras passagens relevantes para o artigo, nenhuma incorreção. Sendo assim, preferi citar da tradução para que os leitores com pouca proficiência em espanhol possam acompanhar a argumentação do artigo. 


\section{1}

Nesse sentido, o poder burocrático que administra a vida em todos os seus aspectos promoveria a sociabilidade, que é naturalmente não-orgânica, através da negação da individualidade e da sua contingência própria, instaurando uma deontologia moral totalitária. O poder burocrático contabilizaria os sujeitos e os submeteria a um dever-ser que captura algumas de suas qualidades e as canaliza para a construção do Todo e do Um. Essa uniformização é o que estabeleceria a comunidade orgânica e inautêntica do regime totalitário, não como finalidade última do processo, mas como meio segundo o qual a vida em si mesma é possível. Nesse sentido, de acordo com essa visão, a "macrofísica" do poder burocrático se oficializaria na microfísica do poder que censuraria a tudo e a todos e eliminaria toda e qualquer diferença em prol do Uno como retrato fiel do Grande Outro (MAFFESOLI, 2001). Com isso, a autonomia individual pareceria irremediavelmente perdida, e, com ela, toda a noção de responsabilidade. Nesse mecanismo, o Mal é de responsabilidade do totalitarismo, e o sujeito em contato com o regime não estaria resguardado disso, cabendo a ele apenas afastarse ou negar-se à submissão para manter a sua inocência. Se for assim, então

[...] apenas aqueles que se retiraram completamente da vida pública, que recusaram a responsabilidade política de qualquer tipo, puderam evitar tornar-se implicados em crimes, isto é, puderam evitar a responsabilidade legal e moral. Na discussão tumultuada das questões morais que tem ocorrido na Alemanha nazista [o texto é de 1964] e a descoberta da total cumplicidade de todas as camadas da sociedade oficial nos crimes, isto é, do colapso total dos padrões morais normais, o seguinte argumento tem sido proposto em intermináveis variações: nós, que parecemos culpados, somos de fato aqueles que permanecemos no emprego para impedir que coisas piores acontecessem; apenas aqueles que permaneceram dentro do sistema tinham uma chance de mitigar a situação e ajudar pelo menos algumas pessoas; pagamos o tributo ao diabo sem lhe vender a nossa alma, enquanto aqueles que nada fizeram furtaram-se a todas as responsabilidades e só pensaram em si mesmos, na salvação de sua preciosa alma. (ARENDT, 2004, pp. 96-97)

Trata-se, mais uma vez, de Sammer: não há responsabilidade total sobre os crimes, porque não há, verdadeiramente falando, um indivíduo a ser considerado. Se o totalitarismo transforma todos em um só, então esse Um é o verdadeiro responsável pelo todo, cosmicamente respondendo pelo princípio e pelo fim de tudo o que aconteceu e pode ser imputado ao Partido. Em outras palavras, Hitler, como primum movens, seria a origem de tudo e tudo se conectaria a esse princípio. É preciso recordar que, no contexto do regime nazista, os atos pessoais são sempre atos "públicos", no sentido de que não são feitos por determinação pessoal, nem podem ser desfeitos por vontade de um indivíduo qualquer; em vez disso, todo ato pessoal sob a égide do Partido é um ato para o Partido e, como tal, responde a uma só racionalidade, uma só intencionalidade, de modo que o sujeito e o corpo que o praticam são, no máximo, um instrumento da Vontade do Partido. Sem vontade, portanto, o indivíduo se anula. O que não se explica, porém, é que no âmbito da administração total da vida haja, ainda, espaço e tempo para decisões. O intervalo entre a ordem e o automatismo de seu cumprimento, ou mesmo o intervalo entre o erro e a ordem final, no caso de Sammer, revelam não tanto a hesitação dos escrúpulos pessoais, como ele quer 


\section{1 tringa}

fazer parecer, mas sim a "deficiência" do totalitarismo que, para todos os efeitos, depende ainda da obediência, civil e psíquica, do seu agente.

Antes de sair disse à minha secretária que se houvesse algo urgente podia me localizar no bar da estação. Já na rua, ao virar uma esquina, me encontrei com o prefeito, o senhor Tippelkirsch, que vinha me ver. Vestia um sobretudo, um cachecol que o tapava até o nariz e vários suéteres que engordavam sobremaneira sua figura. Explicou que não tinha podido vir antes porque estava com quarenta graus de febre. Não exageremos, disse a ele sem parar de andar. Pergunte ao doutor, disse ele atrás de mim. Ao chegar à estação encontrei vários camponeses que esperavam a chegada de um trem regional procedente do leste, da zona do Governo Central. O trem, me informaram, estava com uma hora de atraso. Tudo eram más notícias. Tomei um café com o senhor Tippelkirsch e estivemos falando dos judeus. Estou a par, disse o senhor Tippelkirsch pegando com ambas as mãos sua xícara de café. Tinha mãos muito brancas e finas, cruzadas de veias.

Por um momento pensei nas mãos de Cristo. Mãos dignas de serem pintadas. Depois perguntei o que podíamos fazer. Devolvê-los, disse o senhor Tippelkirsch. Do seu nariz escorria um fiozinho de água. Indiquei-o com o dedo. Não pareceu me entender. Assoe o nariz, falei. Ah, desculpe, disse ele, e depois de procurar nos bolsos do sobretudo tirou fora um lenço branco, muito grande e não muito limpo.

- Como vamos devolvê-los? - perguntei. - Por acaso tenho um trem à minha disposição? E se tivesse: não deveria ocupá-lo com algo mais produtivo?

O prefeito sofreu uma espécie de espasmo e deu de ombros.

- Bote-os para trabalhar - falou.

- E quem os alimenta? A administração? Não, senhor Tippelkirsch, repassei todas as possibilidades e só há uma viável: delegá-los a outro organismo.

- E se, provisoriamente, emprestássemos a cada camponês da nossa região um par de judeus, não seria uma boa ideia? - disse o senhor Tippelkirsch. - Pelo menos até descobrirmos o que fazer com eles.

Olhei-o nos olhos e baixei a voz:

- Isso vai contra a lei, o senhor sabe - falei.

- Bem - disse ele -, eu sei, o senhor também sabe, mas nossa situação não é boa e não cairia mal um pouco de ajuda, não creio que os camponeses iam protestar - falou.

- Não, nem pensar - disse eu. (BOLAÑO, 2010, pp. 718-719)

Esse longo trecho comprova que nos interstícios da decisão pessoal e de sua performance pública há alternativas e possibilidades que dão ao sujeito a certeza de autonomia e de abertura ética que, diferentemente do que postula a concepção acima, não capitulam ao regime totalitário. 0 senhor Tippelkirsch insinua alternativas, nem tão engenhosas, mas bastante pragmáticas, fazendo uma espécie de "advogado do Anjo", em oposição à fria índole administrativa e legalista do oficial alemão. De certa forma, Sammer se vangloria de dar pão aos judeus, ou mesmo até de tê-los posto para varrer a cidade fantasma, vazia e desolada, dando-Ihes alguma ocupação. Parece mesmo que, 


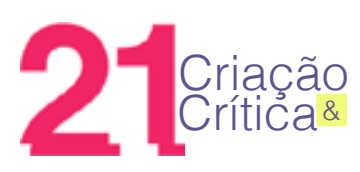

ao contar sua história para Reiter, Sammer se envaidece de ter demonstrado um alto nível de reflexão, de consciência, de imersão no problema, travando sua batalha única e pessoal com os seus escrúpulos e com as determinações maquiavélicas da cartilha tácita do nazismo. Se é assim, e se há espaço para a remissão mesmo no mais desfavorável dos contextos (em que o risco de morte é, infelizmente, real), então a liberdade do sujeito não está irremediavelmente perdida, e ele pode assenhorar-se do seu destino e da sua ação, reavendo a sua identidade-ipseidade no plano ético.

Ora, afinal é disso que se trata quando nos deparamos com Sammer. A consciência da dívida moral, aliada à sua necessidade de remissão, lhe permite separar o que é obra sua do que é obra dos outros, o que ele faz livremente por determinação própria, de um lado, e, de outro lado, o que ele faz por força dos compromissos e responsabilidades públicas com o Partido. "Outro em meu lugar - disse Sammer a Reiter - teria matado com as próprias mãos todos os judeus. Eu não fiz isso. Não é do meu caráter" (BOLAÑO, 2010, p. 729, destaque meu) -, eis a desculpa de Sammer, apresentada publicamente a Hans Reiter. A alegação de que o seu caráter conservou-se intacto durante toda a vigência do nazismo e em meio às tarefas do serviço burocrático somente pode ser feita se houver a distinção plenamente consciente e totalmente autônoma entre o Bem e o Mal - mesmo que, muito casuisticamente, o Bem seja oriundo do sujeito e o Mal, do regime nazista. Creio, inclusive, que a confissão de Sammer aos ouvidos de Hans Reiter é uma tentativa de recuperar a dimensão ética do eu, ou melhor, de reafirmá-la mesmo na adversidade - muito embora isso seja, contraditoriamente, a sua ruína. Acuado, Sammer recapitula o seu passado e reintegra à sua identidade apenas aquilo que se deriva de sua autonomia, relativizando, sem se dar conta disso, a onisciência, a onipotência e a onipresença da burocracia estatal. ${ }^{4}$

Ao que parece, portanto, Sammer, num movimento bastante ricoeuriano, põe-se no lugar do Outro (Reiter ou principalmente os seus condenadores) no intuito de rever suas ações em vista de uma "estima de si" que se manifesta eticamente na dimensão da palavra, da ação, da piedade e da caridade. Desse lugar, Sammer pode dizer perfeitamente, de si para simesmocomoOutro, que, no final das contas, tudo o que ele realmente fez - isto é, aquilo que é responsabilidade sua e de mais ninguém -, aquilo pelo que ele pode ricoeurianamente afirmar "eis-me aqui!", fundindo a identidade narrativa da personagem à intencionalidade doadora de sentido para a ação, é apenas e tão-somente a boa ação. Assim, Sammer praticamente alega: "fui ético, na medida em que alguém poderia ter sido ali", o que, para todos os efeitos, equivale a desmentir a potência do regime, afirmando a potência do sujeito.

4 Bolaño, aliás, é bastante cínico, a meu ver, a respeito do quão "poderoso" é o aparelho de estado nazista, representando-o ironicamente como um emaranhado confuso de departamentos, funcionários, burocratas, onde as decisões e as instruções se perdem juntamente com as responsabilidades pessoais pelos erros. Ninguém se responsabiliza pelo extravio dos judeus. Tampouco ninguém parece ter qualquer plano de contingência para uma situação que, num contexto de guerra e dada a extensão do aparato burocrático, deveria ser até banal e corriqueira. Os SS simplesmente parecem não se importar com o erro, da mesma forma que deixam inteiramente na mão de Sammer, por um período de tempo considerável, a decisão sobre o que fazer. Aparentemente, o aparato nazista não alcança as extremidades do interior da Polônia, mesmo que o escritório central esteja a poucos quilômetros dali. Dessa forma, parece fazer pouco sentido - ou só faz sentido num nível estritamente psicanalítico - a ameaça de morte por traição ou por improbidade no caso de conceder a liberdade aos judeus. Sammer, contudo, orientado a ver somente a ameaça mesmo onde ela não está, comporta-se como o neurótico por excelência, que acredita que o Pai está observando pelo buraco da fechadura mesmo quando não há fechadura, buraco ou, principalmente, Pai. O modo kafkiano pelo qual Bolaño dá destaque a isso nos impressiona de duas maneiras: primeiramente, pelo fato de que a burocracia só existe enquanto espectro, sem realidade palpável; em segundo lugar, porque, apesar disso - ou talvez justamente por isso -, ela é mais assombrosa, lançando os sujeitos na negação cínica de sua inverdade, a fim de melhor justificar seus deslizes. Apenas para saciar a curiosidade, eis um trecho brilhante: "Um oficial me fez assinar uns papéis confirmando que me entregava quinhentos judeus, entre homens, mulheres e crianças. Assinei. Depois telefonei a um amigo, que me pôs em contato com um sujeito que dirigia um campo de judeus perto de Chelmno. Expliquei meu problema, perguntei o que podia fazer com os meus judeus. [...] O sujeito de Chelmno me disse que ligasse para ele dali a dois dias, que ele também, embora eu não acreditasse, tinha problemas diários para resolver" (BOLAÑO, 2010, p. 715). 


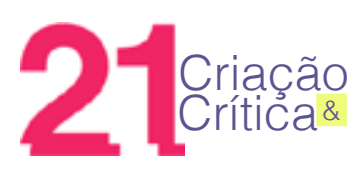

Eis aí, porém, a aporia da alegação de Sammer: ao afirmar-se ético perante Reiter, Sammer pretende renegar esse Grande Outro do regime totalitário. Pode-se dizer, então, que, desse ponto de vista, Sammer visa à afirmação categórica da autonomia moral do sujeito em detrimento de todo o mal que provém do regime. Mas, por outro lado, Sammer não cansa de lamentar a morte do filho e a sorte da esposa, encontrando aí um álibi para a inexorabilidade do mal causado pela guerra ou até mesmo pelo destino. Nesse sentido, a fundamentação moral do caráter de Sammer, mesmo que ele não se dê conta disso, está toda dada pela sua autonomia relativa, uma vez que depende do conhecimento e do entendimento da sua situação histórica.

Sammer não é o sujeito kantiano que simplesmente age conforme as determinações da razão pura. Sua situação não é a de quem pode almejar o princípio da ação, descolando-se do contingente. Na contingência pura do trabalho como administrador, a situação impõe o limite da ação. Sammer, portanto, sabe que existe um Outro - isto é, ele pode representar esse Outro, intuí-lo, imaginá-lo, medi-lo, etc.; ele sabe que não há liberdade irrestrita, que, se há liberdade, é justamente no limite da determinação do tempo e do espaço, das possibilidades de entendimento e representação dos fatos e seus liames causais. Então, ainda que reivindique sua própria determinação ética - é onde, para ele, reside seu valor -, Sammer quer se parecer com as personagens trágicas que não alcançam a plenitude do ser moral (plenitude divina) porque estão ancorados na sua existência mortal. Exagero à parte, o que deve ficar claro é que Sammer mira um outro qualquer puramente contingente, o que significa dizer que, por isso, sua ética falha em ser transcendental. Mesmo sendo capaz da decisão própria, ele demonstra a consciência teórica (em termos kantianos) de que sua ação não vale como princípio universal. Sua defesa, inclusive, contém esse teor: "Fui um administrador justo. Fiz coisas boas, guiado por meu caráter, e coisas ruins, obrigado pelo acaso da guerra" (BOLAÑO, 2010, p. 729).

Entendo que, quando é assim, a ética não se resume mais ao sujeito transcendental, nem tampouco ao Outro. Uma ética sem projeto, sem transitividade é, como bem o demonstra Badiou (1995), uma ética falsa. Para Badiou, as dificuldades de se pensar a ética estão sempre do lado do Mesmo, e não do Outro. Posto que a alteridade infinita é a condição mesma na qual experimentamos o mundo, não é possível, para Badiou, representar-nos um Outro absoluto, que esteja além de todas as potenciais diferenças. Uma ética instruída para essa absoluta diferença é uma ética que abandona os princípios relativos ao próprio sujeito: é o sujeito, enquanto se realiza, enquanto concretiza a sua existência, que pode dizer de si o que ele é. E, conforme se efetua, o Mesmo - ou seja, aquilo que lhe é próprio - entra em conta no plano das alteridades. É somente aí que podemos efetivamente avaliar o caráter e a verdade do ser.

Não há ética senão das verdades. Ou, mais precisamente: não há ética senão dos processos de verdade, do trabalho que faz advir a este mundo algumas verdades. A ética deve ser tomada no sentido suposto por Lacan quando ele fala - opondo-se assim a Kant e à temática de uma moral geral - de ética da psicanálise. A ética não existe. Não há senão ética-de (da política, do amor, da ciência, da arte). (BADIOU, 1995, p. 42, destaques do autor) 


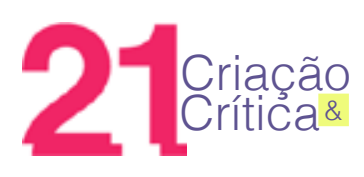

Ponho de lado a referência a Lacan para me focar no elemento transitivo da ética segundo Badiou. É este "de" que contém o segredo do mistério: para Badiou, uma ética kantiana é ineficaz, porque nenhuma ética é sem entendimento, sem projeto, sem uma avaliação da dimensão temporal que encerra a possibilidade mesma de transformação do moral em prática e da prática em lei. Há a ética da política, da ciência e da arte porque há, antes de tudo, a compreensão do que são, no plano prático, as diferentes ações esperadas e valorizadas pelos indivíduos nos seus contextos. Por exemplo, a ética de uma performance artística não se subsome à ética em geral, porque simplesmente a ética em geral não existe. A demanda da arte implica a subjetivação conforme as suas possibilidades concretas, bem como a ética política, a ética pedagógica, a ética do trabalho, a ética sexual etc. Não há ética em geral porque

[...] não há senão um animal particular, convocado pelas circunstâncias a se tornar sujeito. Ou melhor, a entrar na composição de um sujeito. O que quer dizer que tudo o que ele é, seu corpo, suas capacidades, é em certo momento requisitado para que uma verdade faça o seu caminho. Então o animal humano é intimado a ser o imortal que não era. (BADIOU, 1995, p. 53-54, destaque do autor)

Essa requisição do momento é o apelo que a contingência faz ao sujeito ético. Logo, a verdade da ação não se enuncia na epoché, mas sim na imanência do contexto que envolve corpo, desejo, realidade, passado e futuro - o que não significa afirmar o caráter absolutamente pragmático da ética, levando-a mais para o lado de Rorty (2000), por exemplo. Badiou, portanto, insinua que o Mesmo não se encontra além do momento, mas que o Mesmo, inclusive na sua dimensão ética, afunda-se no acontecimento e somente assim se pode avaliá-lo. A vantagem de se pensar a ética nesses moldes está em admitir que o fracasso diante do Mal não decorre do Outro, mas sim do Mesmo. É na medida em que falha, em que falta com a verdade exigida pela ética, que o sujeito incorre no Mal. $E$ isso tem consequências para se pensar o Bem: se o Mal vem do fracasso pessoal, o Bem, por sua vez, também surge com a subjetivação e a performance do sujeito. Para Badiou isso traz o benefício de se poder almejar um projeto qualquer que dê conta de efetuar a transformação coletiva desejada pelo comunismo. Essa abertura ética é em certa medida uma promessa, e as contingências não são, em verdade, empecilhos, mas, pelo contrário, ensejos para a realização da promessa.

Isso nos leva de volta a Sammer: sua falha evidentemente está em tentar separar de modo maniqueísta as instâncias do Bem e do Mal, colocando-se do lado do primeiro e responsabilizando o Grande Outro pelo segundo. Porém, se, como vimos, sua consciência das contingências mostra-se aguda em certos momentos, então sua falta parece ser ainda maior, quando não percebe que a autonomia de fazer o Bem dependia exclusivamente de si. Cabiam a Sammer a alternativa e a possibilidade de fazer mais pelos judeus. Cabia a ele, no limite, não fazer nada, não seguir as ordens (que, como Bolaño mesmo deixa claro, não podiam ser impressas, não criavam contra si nenhuma prova de insubordinação), deixando que os judeus simplesmente escapassem ou se imiscuíssem na população. A tão propalada banalidade do mal reside talvez aí, na facilidade com que se desvinculam o Bem e o Mal da dimensão do Mesmo, quando o Mal está sempre do lado do acusado e o Bem, do lado do inocente, quando a responsabilidade pode facilmente migrar do sujeito verdadeiramente responsável a outrem, mesmo quando este outrem não está ali presente. 


\section{1}

É isso que faz com que a ética de Sammer seja falida. O Outro que ele leva em consideração (o Partido) é facilmente imputável porque justamente não tem um rosto próprio, porque é empiricamente inimputável. Em nenhum momento o Partido pode estar na condição da ipseidade ricoeuriana e dizer "Eis-me aqui!", nem para assumir a culpa, nem para pedir o perdão. Ausente para sempre, ele não é, no entanto, o Deus de Lévinas - ou só o é no seu avesso, o Demônio; ele é, antes, o Pai perverso que obriga o filho à atitude maléfica sob pena de morte (ou castração). Assim, Sammer desconsidera um sem-número de Outros cujos rostos estão ali, dando-se a ver e interpelando eticamente o sujeito. Sammer não dispõe de apenas um, mas sim de quinhentos rostos que surgem do nada, alteridade inabsorvível no Uno da burocracia do Partido, e que, por isso mesmo, abre no nível acontecimal badiouano, bem como no âmbito metafísico levinasiano (LÉVINAS, 2009) a oportunidade de ser ético. Para Lévinas, o Mesmo está limitado sempre ao seu próprio conhecimento, mas nunca ao conhecimento do Outro.

Toda a intencionalidade doadora de sentido às coisas do mundo remete inevitavelmente à consciência pessoal do sujeito que se forma enquanto se abre à experiência, de modo que o Outro também é experiência (ou dado para a consciência) para o sujeito. Extrapolando, portanto, a quinta meditação cartesiana de Husserl (2001), Lévinas quer encontrar o Outro para aquém do dado consciente que transforma o Outro em um "mero" análogo do sujeito cuja consciência o apreende. O rosto do Outro, portanto, na medida mesmo em que está aqui já impõe ao sujeito uma condição para a aventura do seu ser.

O rosto é precisamente a única abertura onde a significância do transcendente não anula a transcendência para fazê-la entrar numa ordem imanente, mas onde, ao contrário, a transcendência se recusa à imanência precisamente enquanto transcendência sempre passada do transcendente. [...] O além donde vem o rosto é a terceira pessoa. O pronome "Ele" exprime sua inexprimível irreversibilidade, quer dizer, fora do alcance de toda revelação e de toda dissimulação - e neste sentido absolutamente não englobável ou absoluta, transcendência num passado absoluto. (LÉVINAS, 2009, p. 62-63, destaque do autor)

Quer dizer, na ética levinasiana, a relação que importa não é a do eu com o tu (primeira e segunda pessoas), mas justamente a do eu com o ele (a terceira pessoa), no sentido de que o rosto que convoca à ação boa não é o rosto daquela situação concreta, mas um rosto talvez mais distante, na distância infranqueável onde se encontra afinal Deus. É isso que faz com que Badiou guarde certa reserva - às vezes excessivamente ácida e, no meu entender, mal dirigida - com a ética segundo Lévinas. Mas, independentemente de como o sagrado e o Deus judaico entram na concepção levinasiana da ética, interessa notar que, para Lévinas, é sempre o Outro que convoca à ação boa, de modo que, pensando em Sammer, os quinhentos rostos ali presentes não são talvez sequer imprescindíveis para se invocar apenas "o" rosto que por si só seria a interdição suficiente para o Mal.

Contudo, o fato é que Sammer tem diante de si os judeus gregos - lá estão eles, como rostos que interpelam como o Outro aquém da autonomia do sujeito. Mas Sammer os ignora, ainda que os veja. Sobrepõe-se a esses rostos o não-rosto do Partido, o que torna a visão de Sammer seletiva no que concerne à autoridade moral sempre transitiva ao "ele" levinasiano. Esses rostos marcados pelo sofrimento não convocam Sammer à boa ação - não do ponto de vista 


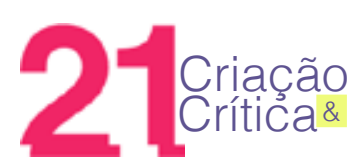

universalista sobre o qual repousa a ética de acordo com Lévinas. Sammer é capaz de nomear e distinguir seus funcionários e os policiais do distrito, mas vê e entende (no sentido kantiano) os judeus apenas como um só e mesmo problema. A desumanização dos judeus não pode ser desfeita pelo pão ou pelo cobertor (insuficientes, ambos), pois essas atitudes só são relevantes do ponto de vista da ética estritamente casuística de Sammer. Na verdade, a desumanização já ocorre ali quando o rosto não se alça à condição de "eleidade" a que se refere Lévinas. Bem por isso, a dimensão ética com a qual se conforma o caráter de Sammer tem a ver, portanto, com esforços pessoais que se valorizam na exata medida em que se impõe aos judeus gregos uma inequívoca condição de inumanidade.

No fundo, Sammer não consegue ultrapassar a reflexão de que se trata de seres-vivos em estado de absoluta carência - e Bolaño carrega nas tintas a fim de salientar a situação quase "animalesca" em que são transportados e em que se encontram quando são desembarcados (o odor do vagão, a compleição silenciosa dos judeus). Difícil não associar esse estado em que os judeus se encontram com o muçulmano ${ }^{5}$ dos campos de extermínio: "O muçulmano é não só, e nem tanto, um limite entre a vida e a morte; ele marca, muito mais, o limiar entre o homem e o não-homem" (AGAMBEN, 2008, p. 62). Como tal, trata-se de um estado de degradação final como obra da perversidade maquínica do campo de concentração e extermínio. Sammer, concretamente, não é o responsável direto pela degradação em que lhe surgem os judeus pela primeira vez; contudo, desse primeiro momento até a solução final ele é sem dúvida o responsável por não apenas negar-lhes um rosto, como também privar-Ihes da dignidade humana demandada pela mera presença do rosto, perpetuando, portanto, a inclemência nazista para com a vítima inocente.

Isso, porém, não conclui a trajetória de Sammer no romance de Bolaño. Depois das tentativas frustradas de encontrar os verdadeiros responsáveis pelos judeus a fim de, se possível, devolvê-los ao órgão competente, Sammer é informado pelo telefone de que "[...] o melhor e mais conveniente é que o senhor mesmo se desfaça deles" (BOLAÑO, 2010, p. 722). A partir daí, Sammer mergulha no desespero: "Naquela noite não pude dormir. Compreendi que o que me pediam era que eliminasse os judeus gregos por minha conta e risco" (BOLAÑO, 2010 p. 722). Sammer então convoca uma reunião com o chefe dos bombeiros, o chefe da polícia e o presidente da Associação dos Veteranos de Guerra, com o intuito de comunicar-lhes a ordem recebida - à qual ninguém se opõe - e na tentativa de organizar a tarefa. Em poucos dias, Sammer dispôs de oito policiais, além de seus secretários, dois funcionários administrativos, seu chofer e ainda dois granjeiros que se ofereceram voluntariamente para o trabalho de extermínio dos judeus. O que era, então, uma responsabilidade pessoal passa a ser uma responsabilidade compartilhada, uma responsabilidade pública e comum: Sammer convoca seus subordinados e os envolve como cúmplices e como algozes do assassinato dos judeus, estendendo os tentáculos do regime às pessoas que nem sequer participavam de fato do Partido. A participação dos granjeiros é um requinte de crueldade bolañesco, mas que põe em perspectiva a falência ética da sociedade sob o regime totalitário nazista, pois, mesmo que distantes do problema e consequentemente alheios à solução final, os granjeiros (mas também os oficiais

5 Não se trata de um adepto do islã, mas sim de uma gíria interna dos prisioneiros dos campos de concentração e extermínio para designar o judeu que, desprovido já de qualquer memória, desejo, esperança e, muitas vezes, até mesmo de linguagem, anda encurvado. O "muçulmano", na linguagem dos Lager, é, de acordo com Jean Améry, "[...] o prisioneiro que havia abandonado qualquer esperança e que havia sido abandonado pelos companheiros, já não dispunha de um âmbito de conhecimento capaz de lhe permitir discernimento entre bem e mal, entre nobreza e vileza, entre espiritualidade e não espiritualidade. Era um cadáver ambulante, um feixe de funções físicas já em agonia" (apud AGAMBEN, 2008, p. 49). 


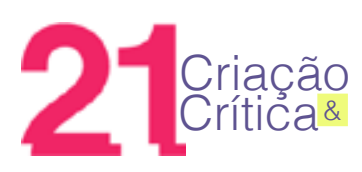

e os funcionários da administração) dão seu consentimento ao Mal, misturando razões pessoais com razões de Estado. É verdade que Bolaño nada nos diz acerca das motivações pessoais dos granjeiros; sabemos apenas que no começo eram dois, passaram a seis e acabaram em um, de modo que só podemos especular sobre a capacidade de mobilização para o crime quando os laços sociais já estão a tal ponto esgarçados ou rompidos que ninguém mais se pergunta como nem por que é possível transformar pessoas comuns em assassinos ou cúmplices. Aliás, o peso da tese arendtiana da "banalidade do mal" consiste acima de tudo nisso: "[...] o que nos perturbou não foi o comportamento dos nossos inimigos, mas o de nossos amigos, que não tinham feito nada para produzir essa situação" (ARENDT, 2004, p. 86).

O mais contundente, porém, está no evento posterior: quando os policiais e os homens da entourage de Sammer começam a sentir o cansaço e o peso moral da tarefa - os assassinatos foram organizados em turnos diários, em grupos de quinze judeus, cada -, Sammer coopta meninos poloneses para atuarem no grupo de extermínio. São meninos que "[...] jogavam na rua com uma bola de trapo e suas corridas e pulos eram verdadeiramente lamentáveis, pois o álcool ingerido os fazia cair a todo instante ou perder gols feitos" (BOLAÑO, 2010, p. 714-715), alheios a tudo o que se refere à guerra, ao nazismo ou aos problemas de Sammer. Para convencê-los, Sammer abdica de todo escrúpulo:

Na segunda-feira seguinte, em vez de sair com as brigadas de varredores para fora do povoado, os policias esperaram o aparecimento dos meninos futebolistas. Ao todo, me trouxeram quinze meninos.

Mandei introduzi-los no auditório da prefeitura e para lá me dirigi acompanhado de meus secretários e do meu chofer. Quando os vi, tão sumamente pálidos, tão sumamente magros, tão sumamente necessitados de futebol e de álcool, senti piedade deles. Mais do que meninos, pareciam ali, imóveis, esqueletos de meninos, esboços abandonados, vontade e ossos.

Disse que haveria vinho para todos eles e também pão e salsichas. Não reagiram. Repeti o vinho e a comida e acrescentei que provavelmente também haveria algo para levarem às suas famílias. Interpretei o silêncio deles como uma resposta afirmativa e os enviei ao grotão a bordo de um caminhão, acompanhados por cinco policiais e um carregamento de dez fuzis e uma metralhadora que, segundo me informaram, engasgava sem mais nem menos. Depois ordenei que o resto da polícia, acompanhada por quatro camponeses armados, que obriguei a participar sob pena de denunciar seus roubos contínuos contra o Estado, levasse para o grotão três brigadas completas de varredores. Também dei ordens para que naquele dia não saísse do antigo curtume nenhum judeu, sob nenhum pretexto. (BOLAÑO, 2010, p. 726)

A transferência de responsabilidade nesse caso é estarrecedora. Sammer, em seu desespero e urgência, corrompe os meninos, inserindo um elo a mais na longa cadeia de maldades perpetrada pelo nazismo. E quando o faz, ele se torna, para todos os efeitos, aquilo de que ele a duras penas quer se distinguir. Vimos mais acima o quanto é importante, na defesa de Sammer, a distinção entre a autonomia do sujeito que pratica o Bem e a ação criminosa que lhe é imposta pelo Grande Outro que virtualmente lhe ameaça de morte. Agora, porém, ao envolver os meninos 


\section{1}

bêbados em seus crimes, Sammer não pode mais afirmar que sua ação é legítima, mesmo do seu ponto de vista distorcido. $O$ seu gesto é completamente autônomo; não é determinado por nenhuma lei exterior. Sammer forma a ideia de corromper os meninos e a põe em prática com a escandalosa frieza que só o desespero e a angústia podiam lhe trazer. Ele põe a serviço do regime toda a sua racionalidade e a sua capacidade administrativa para a solução final - obstinação que, curiosamente, contrasta com o caso das batatas perdidas pelos camponeses que supostamente as estavam escondendo, sem que Sammer os punisse de alguma forma. Leo Sammer corrompe os meninos da mesma forma que alega ter sido corrompido pelo regime nazista, e, nesse ponto, sua defesa não apenas cai por terra, como também fica escancarado o casuísmo ético típico do caráter dos que se consideram inocentes apesar de tudo.

Agora, no entanto, os meninos poloneses bêbados abrem a boca e dizem que eu arruinei a infância deles, disse Sammer a Reiter. Eu? Eu arruinei a infância deles? O álcool é que arruinou! O futebol é que arruinou! Aquelas mãos vadias e sem critério é que arruinaram! E não eu. (BOLAÑO, 2010, p. 729)

Da consciência de Sammer não emana nenhum crime, nenhum pecado. Sua defesa insiste em sua integridade moral, ainda que à força do esfacelamento moral do Outro. Sammer não enxerga o rosto dos judeus, assim como não pode enxergar o rosto dos meninos, desfigurados ou não pela bebida. Aliás, a bebida, aqui, é a marca da maturidade adulta, como se a corrupção dos menores fosse nada perto da degradação moral a que a bebida os legou. $E$, se bebiam e jogavam futebol, é porque "guerra é guerra", "os tempos eram difíceis" ou as "mães eram negligentes" - palavras que, se Sammer não diz de fato, com certeza as cogita. Os meninos, portanto, não convocam Sammer à ação ética; são, em vez disso, simplesmente convocados ao serviço, à lógica maquínica do trabalho, inserindo-se como que por fatalidade na maligna engenharia de extermínio nazista. Nesse âmbito, como vimos, o sujeito se desautonomiza, mesmo que conscientemente, para melhor servir ao Estado. A lógica de Sammer, por isso, mostra a sofisticação daquele Grande Outro com quem ele quer romper. O primeiro passo é obliterar o rosto do Outro logo ali, unificar, uniformizar a diferença, referenciar tudo ao Um, a ponto de que os meninos sejam tão-somente um plural desse Um (meninos, sem nome, sem vontade própria, sem singularidade). Em seguida, trata-se de arregimentar o Outro, enganá-lo a respeito de sua autonomia, fazê-lo crer que não há sujeito para além do Um e daí orientar a sua ação para a prática do Partido. O suborno, nesse caso, não é decisivo enquanto recompensa ou quid pro quo, mas apenas como marca da "bondade" infinita desse um que zela pelo próximo. Finalmente, tudo depende de fazer crer que o pacto é eterno, inviolável, sem passado e sem futuro, porque constantemente presente, como se a cumplicidade não apenas jamais pudesse ser descoberta e revelada, mas simplesmente contraditada, negada por qualquer outra mentalidade, entendimento ou moral. No fim das contas, se o status quo mudar (como de fato aconteceu com a queda do Terceiro Reich), tudo dependerá de que os cúmplices silenciem sobre sua colaboração como qualquer adulto perfeitamente 


\section{1}

consciente de sua obrigação para com o regime nazista, a fim de que o segredo seja enterrado com os malfeitos que não produzem documento. ${ }^{6}$

O problema aqui é que não se trata de adultos, mas sim de crianças. A engenharia nazista de cooptação depende de uma suspensão da autonomia moral e ética do sujeito. É necessário, porém, que a inocência não seja um predicado do sujeito: se for, então não apenas ele se torna isento de qualquer responsabilidade, como também se institui uma perigosa (aos olhos do Partido) possibilidade de insurgência e insubordinação. $O$ inocente é naturalmente refratário à mentalidade do Partido, porque, em princípio, ele é ingênuo, despreparado cognitivamente para a importante tarefa de realizar a comunidade orgânica por meio da sua própria disposição racional. Nesse sentido, é preciso que haja ainda autonomia para que o regime funcione perfeitamente - autonomia que, como vimos, é reivindicada por Sammer quando se trata de envernizar suas "benfeitorias". No caso dos meninos, e porque se trata de meninos, tal autonomia não existe de antemão, mas Sammer precisa "criá-la" a fim de que sua culpa seja dirimida. É a bebida - e, jocosamente, o futebol - que define a capacidade ética dos meninos: se eles se embriagam, pensa Sammer, então eles já estão no grau de autonomia requerida para fazê-los entender que os tempos são difíceis, que, como ele sempre dizia, "a guerra era a guerra e que mais valia entender tudo, tudo, tudo" (BOLAÑO, 2010, p. 712), enfim, para chamá-los à responsabilidade coletiva que favorece o regime nazista, tanto no que diz respeito à eficiência em atingir os propósitos, quanto no que tange ao compartilhamento da culpa. Somente assim Sammer pode insistir na sua autoimagem idealizada de um funcionário eficiente e cumpridor, mas isento de responsabilidade quanto aos crimes que cometeu ou ajudou a cometer.

No final das contas, se os meninos atuam como carrascos e se lhes sobra alternativa, é algo que não nos compete dizer. A sua autonomia não está em questão - e alguma presunção de inocência é cabível aqui. O que está em questão é a postura de Sammer, esta sim falida no que concerne à ética, imperdoável "apesar de tudo". De toda forma, a confissão de Sammer a Reiter não passa incólume. Poucos dias depois, o cadáver estrangulado de Sammer é encontrado pelos soldados americanos. Interrogados, os prisioneiros alemães, inclusive Reiter, não dão nenhuma informação que aponte o assassino. Tudo fica por isso mesmo... até que, muitas páginas depois, Bolaño nos revela que Reiter fizera justiça com as próprias mãos, matando um homem pela primeira e única vez na vida. Mas o assassinato perpetrado por Reiter, a sua responsabilidade, a sua culpa e a sua dimensão ética são assunto para outra ocasião.

\section{Referências}

AGAMBEN, G. O que resta de Auschwitz: o arquivo e a testemunha (Homo Sacer III). Tradução de Selvino J. Assmann. São Paulo: Boitempo, 2008.

ARENDT, H. "Responsabilidade pessoal sob a ditadura". In: Responsabilidade e julgamento. Tradução de Rosaura Eichenberg. São Paulo: Companhia das Letras, 2004.

6 Quando informado de que teria que dar cabo dos judeus ele mesmo, Sammer pede a ordem por escrito, tentando obviamente ter uma caução em caso de mudança do status quo. Ele, no entanto, recebe a seguinte respoșta: "Não seja ingênuo - disse a voz sem a menor arrogância -, essas ordens nunca são dadas por escrito" (BOLAÑO, 2010, p. 722). Obviamente a administração do Reich não pretendia deixar provas que a incriminasse perante os inimigos. Isso, aliás, fomenta uma série de divergências a respeito das cifras dos mortos nos campos de extermínio, debate que, a meu ver, acompanhando Pierre Vidal-Naquet (1988), apenas favorece revisionismos hediondos que desesperadamente tentam atenuar o horror da Shoah. 


\section{1}

Eichmann em Jerusalém. Um relato sobre a banalidade do mal. Tradução de José Rubens Siqueira. São Paulo: Companhia das Letras, 1999.

BADIOU, A. Ética. Um ensaio sobre a consciência do Mal. Tradução de Antônio Trânsito e Ari Roitman. Rio de Janeiro: Relume-Dumará, 1995.

BOLAÑO, R. 2666. Tradução de Eduardo Brandão. São Paulo: Companhia das Letras, 2010.

. "Discurso de Caracas". In: BOLAÑO, Roberto. Entre paréntesis. Ensayos, artículos y discursos (1998-2003). Edición de Ignacio Echevarría. Barcelona: Editorial Anagrama, 2004.

HUSSERL, E. Meditações cartesianas. Introdução à fenomenologia. Tradução de Frank de Oliveira. São Paulo: Madras, 2001.

LÉVINAS, E. Humanismo do outro homem. Tradução de Pergentino S. Pivatto et alii. Petrópolis: Vozes, 2009.

MAFFESOLI, M. "Totalitarismo e indiferença". In: A violência totalitária. Tradução de Maria Ludovina Figueiredo. Lisboa: Instituto Piaget, 2001.

MARISTAIN, M. Bolaño. A biography in conversations. Tradução inglesa de Kit Maude. Brooklyn, NY: Melville House, 2014.

ORWELL, G. 1984. Tradução de Alexandre Hubner e Heloisa Jahn. São Paulo: Companhia das Letras, 2009.

RICOEUR, P. O si-mesmo como outro. Tradução de Ivone C. Benedetti. São Paulo: Editora WMF Martins Fontes, 2014.

RORTY, R. "Ética sem obrigações universais". In: Pragmatismo: a filosofia da criação e da mudança. Tradução de Cristina Magro e Antonio Marcos Pereira. Belo Horizonte: Editora da UFMG, 2000.

VIDAL-NAQUET, P. Os assassinos da memória: um Eichmann de papel e outros ensaios sobre o revisionismo. Tradução de Marina Appenzeller. Campinas: Papirus, 1988.

Recebido em: 30/04/2018 Aceito em: 24/09/2018

Referência eletrônica: BRITO JUNIOR, Antonio Barros de. A trajetória de Leo Sammer em 2666, de Roberto Bolaño. Notas sobre ética, autonomia e responsabilidade. Criação \& Crítica, n. 21, p.0-15, nov. 2018. Disponível em: <http://revistas.usp.br/criacaoecritica>. Acesso em: dd mmm. aaaa. 